\title{
18. OSMIUM-ISOTOPE GEOCHEMISTRY OF SITE 959: IMPLICATIONS FOR Re-Os SEDIMENTARY GEOCHRONOLOGY AND RECONSTRUCTION OF PAST VARIATIONS IN THE OS-ISOTOPIC COMPOSITION OF SEAWATER ${ }^{1}$
}

\author{
Greg Ravizza²
}

\begin{abstract}
Analyses of Re, Os, and Ir concentrations, as well as Os-isotopic compositions, are reported for a suite of sediments from Ocean Drilling Program Site 959. These samples vary in age from late Neogene to Late Cretaceous, and represent a range in depositional oxidation-reduction conditions from suboxic in the Neogene to anoxic in the Late Cretaceous. Age assignments based on shipboard biostratigraphic data are used to calculate initial ${ }^{187} \mathrm{Os} /{ }^{186} \mathrm{Os}$ ratios of Neogene nannofossil/foraminifer oozes and Eocene to upper Oligocene laminated diatomites. These calculated initial ratios are in general agreement with published data constraining the Os-isotopic evolution of seawater through time, indicating that the Os-isotopic composition of these sediments is controlled largely by the Os isotopic composition of contemporaneous seawater. Results from analyses of Upper Cretaceous to lower Paleocene claystones do not exhibit elevated Ir concentrations and exhibit Re-Os systematics that are highly consistent with closed-system production of ${ }^{187} \mathrm{Os}$ by in situ ${ }^{187} \mathrm{Re}$ decay. Scatter in both the Cretaceous and Cenozoic data sets is likely the result of the influence of nonhydrogenous Os, carried by clastics, on the bulk sediment Os-isotopic composition, or post-depositional mobility of Re and/or Os.
\end{abstract}

\section{INTRODUCTION}

The Re-Os systematics of continental margin sediments from Ocean Drilling Program Site 959, deposited under anoxic to moderately reducing conditions, are examined in this report. Previous work demonstrates that recent, laminated, organic-rich sediments scavenge significant quantities of Os from seawater at the time of deposition, thereby providing a means of inferring the Os-isotopic composition of present-day seawater (Ravizza and Turekian, 1992). Studies of trace-metal-rich, Paleozoic black shales show that the in situ decay of ${ }^{187} \mathrm{Re}$ to ${ }^{187} \mathrm{Os}$ provides a chronologic tool that records dates close to depositional ages determined biostratigraphically (Ravizza and Turekian, 1989; Horan et al., 1994). Together these studies of modern and ancient sediments suggest that Re-Os studies of marine sediments deposited under reducing conditions have the potential to produce isochrons that would yield the age of sediment deposition, and initial ${ }^{187} \mathrm{Os} /{ }^{186} \mathrm{Os}$ ratios that record the Os isotopic composition of contemporaneous seawater at the time of deposition. The results presented here are a first attempt to explore this possibility.

Data in Mascle, Lohmann, Clift, et al. (1996) document that sediments drilled at Site 959 (Fig. 1) provide a long and varied record of sediment deposition under a range of oxidation-reduction conditions. These results are summarized briefly here to place the geochemical and isotopic data in their proper context. During the Late Cretaceous, deposition of laminated black claystone is indicative of fully anoxic bottom water. Poor ventilation of bottom water during this time likely resulted from the Cote d'Ivoire-Ghana Marginal Ridge's obstruction of deep-water circulation in the Deep Ivoirian Basin. While continued rifting led to better ventilation of deep waters, upwelling of nutrient-rich deep waters resulted in episodes of high productivity from the middle Eocene to the early Miocene, recorded by deposition of organic-rich, laminated diatomites. During most of the Neogene, coastal upwelling continued to influence the region. Greater water

${ }^{1}$ Mascle, J., Lohmann, G.P., and Moullade, M. (Eds.), 1998. Proc. ODP, Sci. Results, 159: College Station, TX (Ocean Drilling Program).

${ }^{2}$ Woods Hole Oceanographic Institution, Woods Hole, MA 02543-1541, U.S.A. gravizza@whoi.edu depths and improved deep-water ventilation led to deposition of nannofossil/foraminifer oozes under moderately reducing conditions. Suboxic conditions are inferred to have prevailed during much of this time, based on the weakly bioturbated texture of the sediment and the mixed assemblage of early diagenetic pyrite and glauconite. Thus, the sediments recovered from Site 959 provide a means of exploring Re-Os systematics in moderately reducing sediments, as well as further investigating sediments deposited under fully anoxic conditions.

A survey of the Re-Os systematics of samples from the three distinct lithologies described above is reported here. In the relatively young Neogene nannofossil/foraminifer oozes, the influence of in situ ${ }^{187} \mathrm{Re}$ decay on Os-isotopic composition is small. Therefore, the main point of interest is whether these suboxic sediments accurately record the secular changes in the Os-isotopic composition of seawater identified in more slowly accumulating oxic pelagic deposits from the Pacific (Pegram et al., 1992; Ravizza, 1993; Peucker-Ehrenbrink et al., 1995). In the much older, Upper Cretaceous sections, organicrich, claystone variations in Os-isotopic composition are expected to be influenced much more strongly by in situ ${ }^{187} \operatorname{Re}$ decay. In addition, the Os-isotopic composition of seawater at this time is at present only poorly constrained and largely a matter of speculation. Consequently, the focus of this portion of the Re-Os study is on potential geochronologic applications. The biosiliceous deposits of the Paleogene and very early Neogene lie in a middle ground where corrections for in situ ${ }^{187}$ Re decay are large, but enough data constraining the Os-isotopic composition of seawater are available to provide a backdrop against which calculated initial ${ }^{187} \mathrm{Os} /{ }^{186} \mathrm{Os}$ ratios from the laminated diatomites can be evaluated.

In addition to the Re and Os data, we also report Ir concentrations for the majority of these samples. The impetus for including Ir analyses in this study is twofold. First, in a wide range of terrestrial rocks, Os/Ir ratios are close to 1 (Agiorgitis and Wolfe, 1984); the Ir data may therefore provide a useful indication of what fraction of Os in the sample is associated with mineral detritus rather than derived from seawater. Second, the Upper Cretaceous claystone sequence continues into the lower Paleocene. Therefore, the Upper Cretaceous to lower Paleocene samples were investigated to determine if evidence of an Ir anomaly associated with the Cretaceous/Tertiary boundary could be found. 
Figure 1. Location map showing Site 959 on the Cote d'Ivoire-Ghana Transform Margin.

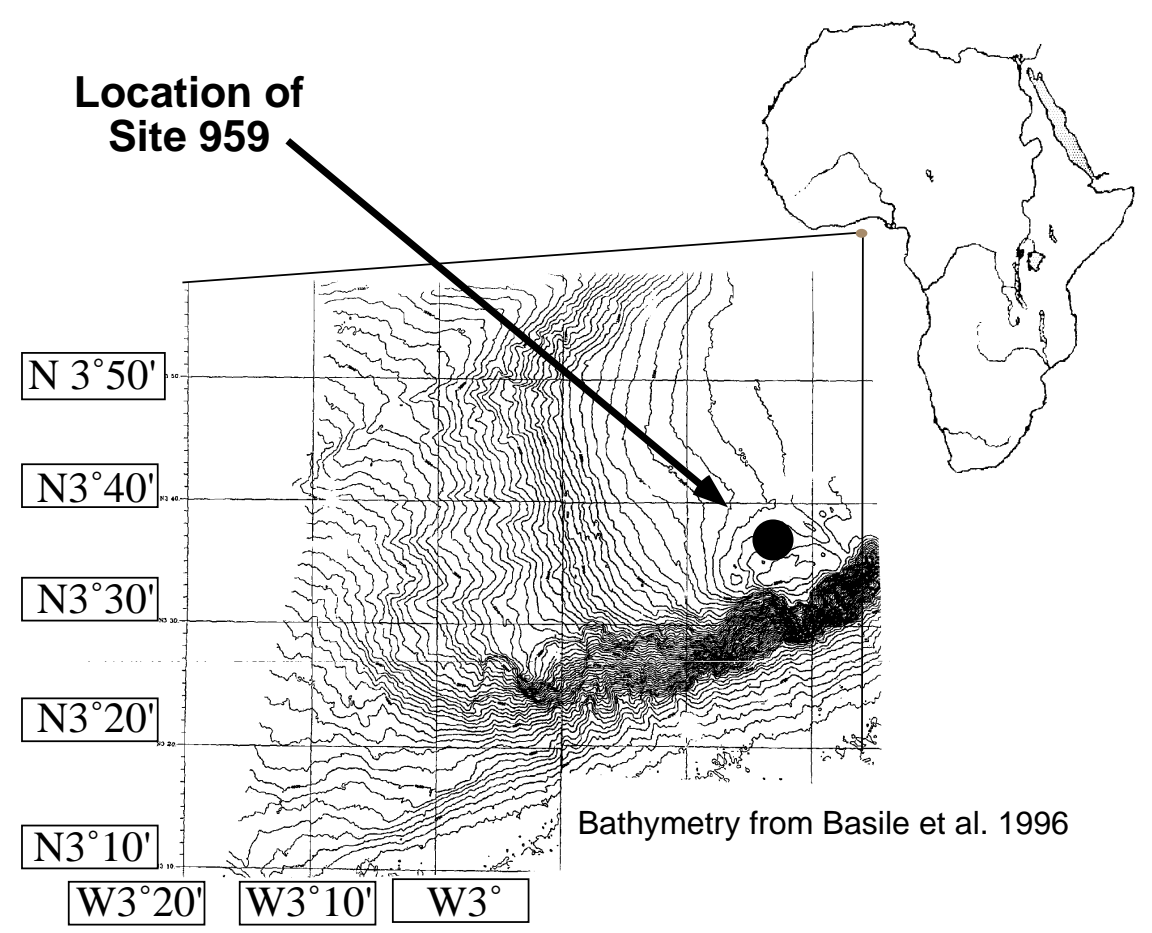

RESULTS

\section{METHODS}

The methods employed in measuring Re, Os, and Ir concentrations, as well as Os isotope measurements, are not discussed in detail here. These methods are described elsewhere, as cited below. All samples were dried overnight in an oven at $90^{\circ} \mathrm{C}$ and ground. Relatively unlithified samples were ground by hand in an agate mortar. Lithified samples were ground in an alumina ceramic shatter box.

All data are from bulk sediment analyses. For Re, samples were dissolved by open beaker acid digestion (Colodner et al., 1993). For Os and Ir, sample digestion was achieved using a nickel sulfide fire assay method. All concentrations were determined using isotope dilution. Re was separated using an established ion exchange procedure followed by isotope ratio measurement by inductively coupled plasma mass spectrometry (ICPMS) (Peucker-Ehrenbrink et al., 1995). Ir was also analyzed by ICPMS, but required no ion exchange separation following the fire assay preconcentration (Ravizza and Pyle, in press). Os required purification by distillation and ion exchange separation following fire assay preconcentration (Esser and Turekian, 1988) prior to isotopic analysis by negative thermal ionization mass spectrometry (Hauri and Hart, 1993). In the tables and figures, variations in Os-isotopic composition are reported using both ${ }^{188} \mathrm{Os}$ and ${ }^{186}$ Os normalizations to make the data accessible to readers familiar with either normalization scheme. In the text, data are discussed using the ${ }^{186} \mathrm{Os}$ normalization. ${ }^{187} \mathrm{Os} /{ }^{186} \mathrm{Os}$ ratios are calculated from measured ${ }^{187} \mathrm{Os} /{ }^{188} \mathrm{Os}$ ratios using ${ }^{186} \mathrm{Os} /{ }^{188} \mathrm{Os}=0.1200$. Precision of the $\operatorname{Re}$ analyses was typically better than $\pm 1 \%$ based on ICPMS counting statistics. However, replicate analyses showed larger variance; typically agreeing at the $\pm 3 \%$ level. Uncertainties in the Os and Ir analyses are controlled by blank corrections required to account for impurities carried by fusion reagents used in the nickel sulfide fire assay. IR concentrations are reproducible at the $\pm 10 \%-15 \%$ level, requiring blank corrections of up to $20 \%$. Blank corrections for Os concentrations were typically $3 \%$ of total analyte and did not exceed $6 \%$, and blank corrections for ${ }^{187} \mathrm{Os} /{ }^{186} \mathrm{Os}$ ratios were usually $1 \%-2 \%$ in magnitude and did not exceed $3.5 \%$.
Results of all analyses are reported in Table 1. The major features of the data set are summarized below, first reviewing concentration variations and then turning to Os-isotopic variations.

\section{Ir Concentrations}

Ir concentrations show little variability and are very similar to typical values of average crustal material of 40 parts per trillion (ppt) (Fenner and Presley, 1984). The shallowest sample analyzed from Site 959 is the single exception, showing a four- to fivefold enrichment over average crustal material. Although this is a significant enrichment, it is not extremely unusual. For example, similar Ir concentrations are observed in fairly common mafic rocks (Ravizza and Pyle, in press). The most noteworthy aspect of the Ir data is that the samples from Cores 159-959D-48R and 49R, which bracket the Cretaceous/Tertiary boundary (Oboh-Ikuenobe et al., Chap. 25, this volume), do not show evidence of elevated Ir concentrations. Thus, the data in hand do not provide any indication that a portion of the Cretaceous/Tertiary Ir anomaly (Alvarez et al., 1980) has been captured in the samples analyzed. It should be noted that samples are separated by $2 \mathrm{~m}$ or more, so that these data do not preclude the presence of an Ir anomaly in sediments recovered from Hole 959D.

\section{Re and Os Concentrations}

In contrast to Ir, Os concentrations are generally higher than the estimated average crustal Os concentration of $40 \mathrm{ppt}$ (Esser and Turekian, 1988), ranging from 460 to 100 ppt. This result is consistent with results from previous works that report similar Os concentrations in marine sediments associated with coastal upwelling (Ravizza and Turekian, 1992). The fact that Os concentrations are elevated relative to average crustal material and to Ir concentrations in the same samples indicates that a significant fraction of the total Os in these samples is hydrogenous in origin (i.e, derived from seawa- 
Table 1. Re, Ir, and Os isotope data from Site 959.

\begin{tabular}{|c|c|c|c|c|c|c|}
\hline $\begin{array}{l}\text { Core, section, } \\
\text { interval }(\mathrm{cm})\end{array}$ & $\begin{array}{l}\text { Depth } \\
\text { (m) }\end{array}$ & $\begin{array}{l}\mathrm{Re} \\
(\mathrm{ppb})\end{array}$ & $\begin{array}{c}\mathrm{Ir} \\
(\mathrm{ppb})\end{array}$ & $\begin{array}{c}\text { Os } \\
(\mathrm{ppb})\end{array}$ & ${ }^{187} \mathrm{Os} /{ }^{188} \mathrm{Os}$ & ${ }^{187} \mathrm{Os} /{ }^{186} \mathrm{Os}$ \\
\hline \multicolumn{7}{|l|}{ 159-959B- } \\
\hline $1 \mathrm{H}-2,145-150$ & 3.0 & 12.7 & 0.244 & 0.132 & 0.937 & 7.81 \\
\hline $2 \mathrm{H}-3,145-150$ & 9.5 & 11.3 & 0.050 & 0.131 & 1.063 & 8.86 \\
\hline $4 \mathrm{H}-3,145-150$ & 28.5 & 14.7 & & 0.099 & 1.016 & 8.47 \\
\hline $5 \mathrm{H}-3,145-150$ & 38.0 & 27.5 & 0.005 & 0.123 & 1.054 & 8.78 \\
\hline $8 \mathrm{H}-3,145-150$ & 57.0 & 20.2 & & 0.113 & 0.964 & 8.03 \\
\hline \multicolumn{7}{|l|}{ 159-959A- } \\
\hline $10 \mathrm{H}-3,145-150$ & 89.6 & 6.3 & 0.020 & 0.129 & 0.983 & 8.19 \\
\hline $34 X-4,145-150$ & 317.0 & 40.9 & 0.030 & 0.199 & 1.073 & 8.94 \\
\hline $46 X-3,145-150$ & 432.1 & 88.9 & 0.030 & 0.309 & 1.306 & 10.88 \\
\hline \multicolumn{7}{|l|}{ 159-959D- } \\
\hline $9 \mathrm{R}-1,145-150$ & 486.0 & 64.3 & 0.040 & 0.463 & 1.109 & 9.24 \\
\hline $12 \mathrm{R}-1,145-150$ & 515.0 & 49.7 & 0.026 & 0.259 & 1.292 & 10.77 \\
\hline $16 \mathrm{R}-1,145-150$ & 553.5 & 13.9 & 0.042 & 0.158 & 0.826 & 6.88 \\
\hline $29 \mathrm{R}-2,145-150$ & 680.1 & 21.1 & 0.014 & 0.166 & 0.865 & 7.21 \\
\hline 48R-3, 41-44 & 864.0 & 11.8 & 0.029 & 0.186 & 0.883 & 7.36 \\
\hline $48 \mathrm{R}-5,110-113$ & 867.7 & 14.3 & 0.035 & 0.222 & 0.803 & 6.69 \\
\hline 49R-1, 89-92 & 871.1 & 6.0 & 0.051 & 0.141 & 0.565 & 4.71 \\
\hline 49R-5, 34-37 & 876.6 & 31.8 & 0.029 & 0.243 & 1.294 & 10.78 \\
\hline $49 \mathrm{R}-6,98-101$ & 878.7 & 3.0 & 0.037 & 0.304 & 0.634 & 5.28 \\
\hline $50 \mathrm{R}-4,41-44$ & 884.8 & 11.7 & 0.038 & 0.132 & 1.144 & 9.53 \\
\hline $50 \mathrm{R}-6,42-45$ & 888.8 & 29.9 & 0.047 & 0.153 & 2.064 & 17.20 \\
\hline 51R-1, 108-111 & 890.3 & 11.1 & 0.031 & 0.129 & 1.081 & 9.01 \\
\hline $51 \mathrm{R}-5,107-108$ & 896.3 & 19.6 & 0.052 & 0.13 & 1.078 & 8.98 \\
\hline $52 \mathrm{R}-3,97-100$ & 902.8 & 10.6 & 0.021 & 0.106 & 1.314 & 10.95 \\
\hline
\end{tabular}

ter). Re concentrations are extremely enriched relative to average crustal concentrations, up to a hundredfold. This, too, has been documented in previous studies of analogous modern sediments (Koide et al., 1986; Colodner et al., 1993) and Paleozoic black shale (Ravizza and Turekian, 1989). It also noteworthy that the highest concentrations of Re and Os occur in samples from Hole 959D with high U content, based on downhole gamma logs (Mascle, Lohmann, Clift, et al., 1996). It is also well documented that in marine sediments, $U$ enrichment is associated with deposition under anoxic (Anderson et al., 1989) and suboxic (Barnes and Cochran, 1990; Klinkhammer and Palmer, 1991) conditions. The association of elevated U, Re, and Os concentrations is therefore not surprising.

\section{Os-Isotope Data}

The ${ }^{187} \mathrm{Os} /{ }^{186} \mathrm{Os}$ ratios of samples analyzed from Site 959 range from 4.7 to 17.2 , with the majority of the data clustering between 7 and 11. The nannofossil-foraminifer oozes, those from shallower than 90 mbsf, show the most limited range in Os-isotopic composition, and are similar to the inferred value of present-day seawater. The Upper Cretaceous to lower Paleocene samples show the most variability in Os-isotopic composition, including the highest and lowest ${ }^{187} \mathrm{Os} /{ }^{186} \mathrm{Os}$ ratios. These samples also exhibit a large range in $\mathrm{Re} /$ Os ratio. As a consequence of these large and variable Re/Os ratios, much of the variability in the Os isotopic composition of these samples reflects variable amounts of in situ production of ${ }^{187} \mathrm{Os}$ by Re decay.

\section{DISCUSSION \\ Os/Ir Ratios}

One of the most important constraints on interpretations of the Os-isotopic variations in these samples is the source from which the Os is derived. Although the high concentrations of Os relative to average crustal material suggest that these samples contain a significant proportion of seawater-derived Os, one cannot eliminate the possibility that the terrigenous component of these sediments carries a higher Os concentration than average crustal material. Relatively insoluble elements, such as $\mathrm{Al}, \mathrm{Ti}$, and $\mathrm{Th}$, provide a means of estimating the fraction of terrigenous material in the sediment (Dymond et al., 1992;

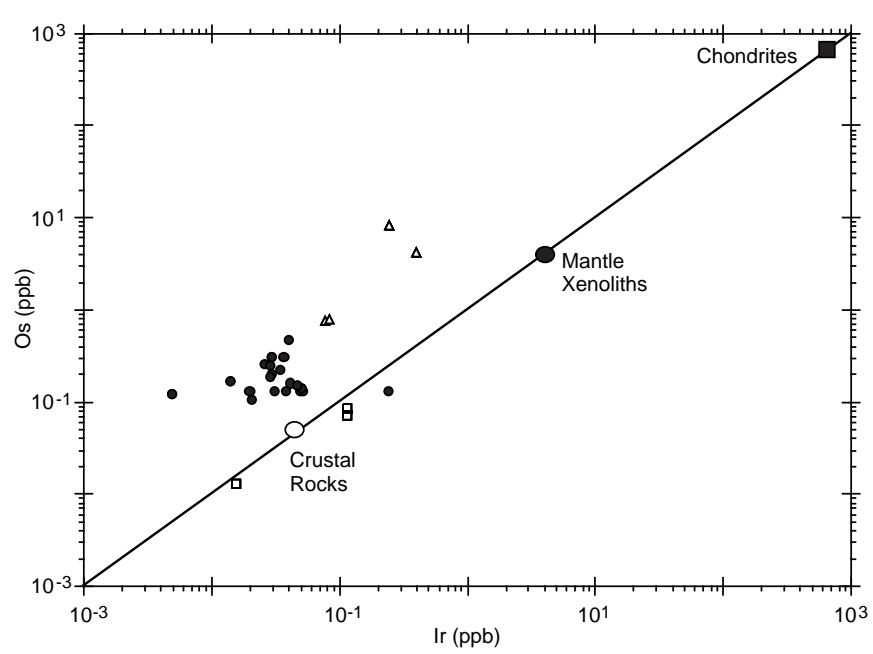

Figure 2. A log-log plot of Os vs. Ir illustrates that Os and Ir are tightly correlated and exhibit a nearly 1:1 ratio over 5 orders of magnitude, ranging from chondrites (solid square; Anders and Grevesse, 1989) to mantle xenoliths (solid circle; Morgan et al., 1981), to crustal rocks. Open squares = basalts (Hertogen et al., 1980) and the open circle = Mississippi River sediment (Fenner and Presley, 1984; Esser and Turekian, 1993). In contrast, tracemetal-rich black shale (open triangles; Orth et al. 1986; Orth et al. 1988) and data from Site 959 (filled circles) exhibit systematically higher ratios, indicative of significant authigenic Os enrichment in reducing sediments.

Murray et al., 1993; Francois et al., 1993). However, Os shares little in common with these elements because it is chalcophile and siderophile, rather than lithophile. As a result these elements are not reliable indicators of the amount of terrigenous Os in organic-rich sediments.

In reducing sediments, Ir should serve as a better indicator of terrigenous Os than the elements mentioned above. Os and Ir are both platinum group elements, and are not readily fractionated from one another by magmatic processes. As a result, Os/Ir ratios in most earth materials are close to the chondritic ratio, approximately 1 (Fig. 2). In reducing aqueous systems these elements exhibit quite different 
behavior. As discussed above, Os tends to be enriched in reducing sediments, but Ir shows no evidence of enhanced scavenging under reducing conditions (Anbar et al., 1996). Based on this contrast in aqueous behavior, Os/Ir ratios close to 1 suggest the predominance of terrigenous Os, while higher ratios reflect an authigenic Os component. Extremely trace-metal-rich black shale has Or/Ir ratios close to 10 (Orth et al., 1986), ratios that may reflect a pure authigenic component (Fig. 2). Data from Site 959 have Os/Ir ratios that are generally greater than one, supporting the inference of appreciable Os enrichment based on Os concentrations alone. Os/Ir ratios of individual samples are considered below, where they have bearing on interpretation of the Os-isotope data.

There is clearly a need for more data constraining the potential range in Os/Ir ratios of terrigenous material. The data reported here are among the only published analyses of both Os and Ir concentrations in the sediment samples. If Os/Ir ratios of terrigenous materials are found to vary widely, using Os/Ir ratios to infer the presence of terrigenous Os in sediments will be of limited utility. The low Os/Ir ratio of sample 159-959B-1H-2, 145-150 cm, as well as the possibility that weathered ancient organic-rich sediments might carry Os/Ir ratios much greater than 1 , highlight this concern. These initial data are nonetheless promising and indicate this area deserves further investigation.

\section{Neogene Nannofossil/Foraminifer Oozes}

Analyses of six samples from the uppermost $90 \mathrm{~m}$ of the sedimentary sequence yield ${ }^{187} \mathrm{Os} /{ }^{186} \mathrm{Os}$ ratios between 7.8 and 8.8 . This is a relatively narrow range in light of the large dynamic range of the Os isotope system, with average continental crustal material estimated to have a ${ }^{187} \mathrm{Os} /{ }^{186} \mathrm{Os}$ ratio between 10 and 11 (Esser and Turekian, 1993), whereas oceanic crust carries ${ }^{187} \mathrm{Os} /{ }^{186} \mathrm{Os}$ ratio close to 1 (RoyBarman and Allégre, 1994). Os isotopic data from these suboxic sediments are similar to the inferred value of present-day seawater, approximately 8.6. The simplest interpretation of this similarity is that much of the Os in these sediments is scavenged from seawater. This result is significant in that it indicates that Os is scavenged under suboxic conditions as well as anoxic conditions.

$\mathrm{Re} / \mathrm{Os}$ ratios of these samples are large and variable. As a consequence, in situ production of ${ }^{187} \mathrm{Os}$ can be significant, up to several percent, on time scales of a few million years. To compare Site 959 data to the record of seawater Os isotopic variations through time, which is based solely on Pacific sediments, requires correction for ${ }^{187}$ Os produced since the time of deposition. To calculate initial ${ }^{187} \mathrm{Os} /$ ${ }^{186}$ Os ratios requires knowledge of the age of the sediment, the halflife of ${ }^{187} \mathrm{Re}$, and the Re/Os ratio of the sediment. This information is given in Table 2 and used to calculate initial ${ }^{187} \mathrm{Os} /{ }^{186} \mathrm{Os}$ ratios. The implicit assumption that underlies this calculation is that each sample has acted as a closed system with respect to Re and Os since the time of sediment deposition. Diagenetic redistribution of Re and/or Os would violate this assumption. In the case of the relatively young nannofossil/foraminifer oozes, age corrections are small and the calculated initial ${ }^{187} \mathrm{Os} /{ }^{186} \mathrm{Os}$ ratios are quite insensitive to uncertainties in sample ages.

Calculated initial ${ }^{187} \mathrm{Os} /{ }^{186} \mathrm{Os}$ ratios are plotted as a function of age along with published data constraining the Os-isotopic evolution of seawater (Fig. 3). Although the 959 data show more scatter than data from oxic Pacific sediments, ${ }^{187} \mathrm{Os} /{ }^{186} \mathrm{Os}$ ratios generally increase with decreasing sediment age, similar to the Pacific data. This result is consistent with the interpretation that hydrogenous Os exerts a strong control over the Os isotopic composition of these sediments. It is also clear that the sediments from Site 959 are somewhat more radiogenic than the Pacific data. Analyses of Mn crust surfaces suggest that the ${ }^{187} \mathrm{Os} /{ }^{186} \mathrm{Os}$ ratio of the Atlantic $(8.80 \pm 0.07)$ may be

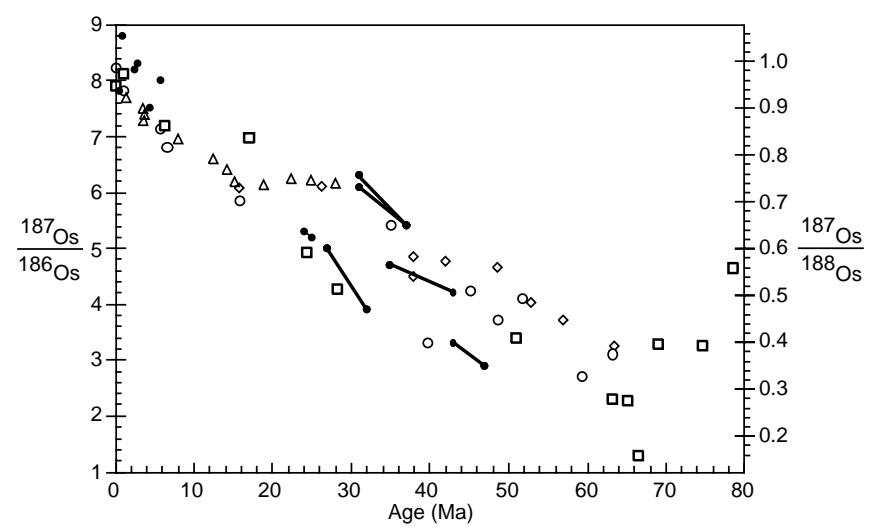

Figure 3. Plot of ${ }^{187} \mathrm{Os} /{ }^{186} \mathrm{Os}$ ratio vs. age representing the Os-isotopic composition of seawater through time as inferred from analyses of marine sediments. Open symbols = published data from analyses of oxic Pacific sediments: open triangles $=$ metalliferous sediment data from Ravizza (1993); open diamonds $=$ metalliferous sediment data from PeuckerEhrenbrink et al. (1995); open circles = pelagic clay data from Pegram et al. (1992), and open squares = pelagic clays, Peucker-Ehrenbrink et al. (1995). Site 959 analysis data samples $=$ solid circles. The ${ }^{187} \mathrm{Os} /{ }^{186} \mathrm{Os}$ ratios plotted are calculated initial values given in Table 2. The linear arrays arise from poorly constrained biostratigraphic age assignments.

Table 2. Calculation of initial Os-isotope ratios of Neogene nannofossil oozes and late Oligocene to Eocene laminated diatomites.

\begin{tabular}{|c|c|c|c|c|c|}
\hline Sample & ${ }^{187} \mathrm{Os} /{ }^{186} \mathrm{Os}$ & ${ }^{187} \mathrm{Re} /{ }^{186} \mathrm{Os}$ & Age (Ma) & $\begin{array}{c}\text { Initial } \\
{ }^{187} \mathrm{Os} /{ }^{186} \mathrm{Os}\end{array}$ & $\begin{array}{c}\text { Initial } \\
{ }^{187} \mathrm{Os} /{ }^{188} \mathrm{Os}\end{array}$ \\
\hline \multicolumn{6}{|l|}{ 159-959B- } \\
\hline $1 \mathrm{H}-2,145-150$ & 7.81 & 4277 & $0.5 \pm 0.1$ & 7.8 & 0.94 \\
\hline $2 \mathrm{H}-3,145-150$ & 8.86 & 3893 & $1.0 \pm 0.2$ & 8.8 & 1.06 \\
\hline $4 \mathrm{H}-3,145-150$ & 8.47 & 6650 & $2.5 \pm 0.1$ & 8.2 & 0.98 \\
\hline $5 \mathrm{H}-3,145-150$ & 8.78 & 10044 & $2.9 \pm 0.2$ & 8.3 & 1.00 \\
\hline $7 \mathrm{H}-3,145-150$ & 8.03 & 7946 & $4.4 \pm 0.4$ & 7.5 & 0.90 \\
\hline \multicolumn{6}{|l|}{ 159-959A- } \\
\hline $10 \mathrm{H}-3,145-150$ & 8.19 & 2176 & $5.9 \pm 0.3$ & 8.0 & 0.96 \\
\hline $34 X-4,145-150$ & 8.94 & 9254 & $24-25$ & $5.2-5.3$ & $0.62-0.64$ \\
\hline $46 X-3,145-150$ & 10.88 & 13306 & $27-32$ & $3.9-5.0$ & $0.47-0.60$ \\
\hline \multicolumn{6}{|l|}{ 159-959D- } \\
\hline $9 \mathrm{R}-1,145-150$ & 9.24 & 6278 & $31-37$ & $5.4-6.1$ & $0.65-0.73$ \\
\hline $12 \mathrm{R}-1,145-150$ & 10.77 & 8857 & $31-37$ & $5.4-6.3$ & $0.65-0.76$ \\
\hline $16 \mathrm{R}-1,145-150$ & 6.88 & 3836 & $35-43$ & $4.2-4.7$ & $0.50-0.56$ \\
\hline $29 \mathrm{R}-2,149-150$ & 7.21 & 5577 & $43-47$ & $2.9-3.3$ & $0.35-0.40$ \\
\hline
\end{tabular}

Notes: Tabulated ages are derived from biostratigraphy in Mascle, Lohmann, Clift, et al. (1996) and the geologic time scale adopted in that report. Calculated initial ${ }^{187}$ Os $/{ }^{186}$ Os ratios based on the ${ }^{187} \mathrm{Re}$ decay constant reported by Lindner et al. (1989). 
slightly higher than the Pacific (8.61 \pm 0.08 ; Burton et al., 1996). Sample 159-959B-2H-3, $145-150 \mathrm{~cm}$, has a ${ }^{187} \mathrm{Os} /{ }^{186} \mathrm{Os}$ ratio that is indistinguishable from the Atlantic Mn crust data and may reflect the Os isotopic composition of contemporaneous seawater. The low ${ }^{187} \mathrm{Os} /{ }^{186} \mathrm{Os}$ ratio of the youngest sample, $159-959 \mathrm{~B}-1 \mathrm{H}-2,145-150$ $\mathrm{cm}$, in conjunction with a high Ir concentration (Table 1) and Os/Ir ratios below 1, suggest the presence of an unradiogenic terrigenous component at Site 959. The influence of a terrigenous component carrying ${ }^{187} \mathrm{Os} /{ }^{186} \mathrm{Os}$ lower than seawater is significant because it implies that the offset between Pacific and Atlantic data in Figure 3 is unlikely to reflect elevation of the Atlantic data by a radiogenic terrigenous component. Thus, based on the available data, it seems more reasonable to interpret the offset between Pacific and Atlantic samples as a subtle contrast in hydrogenous Os isotopic composition between the two ocean basins.

\section{Late Oligocene to Eocene Laminated Diatomites}

The scheme for interpreting data from these much older laminated diatomite samples is analogous to the approach described above for the nannofossil/foraminifer oozes. The significant difference lies in the fact that the magnitude of the age corrections is large. The age assignments are based on shipboard biostratigraphy, and large portions of the biosiliceous sequence from Site 959 were found to be barren of age-diagnostic microfossils. The resulting uncertainty in sediment age gives rise to uncertainties in the calculated initial ${ }^{187} \mathrm{Os} /{ }^{186} \mathrm{Os}$ ratios. Ranges in calculated initial ${ }^{187} \mathrm{Os} /{ }^{186} \mathrm{Os}$ ratio for each sample are reported in Table 2. Figure 3 shows that each sample produces a line on the ${ }^{187} \mathrm{Os} /{ }^{186} \mathrm{Os}$ vs. age plot, representing an array of calculated initial ratios, corresponding to a given range of possible ages. This occurs because calculated initial ${ }^{187} \mathrm{Os} /{ }^{186} \mathrm{Os}$ ratios are related linearly to the age through the correction for in situ production of ${ }^{187} \mathrm{Os}$ by $\mathrm{Re}$ decay.

Published Pacific data shown in Figure 3 show more scatter in the Oligocene and Eocene than in the Neogene, making it more difficult to discern with any degree of precision whether or not calculated initial ${ }^{187} \mathrm{Os} /{ }^{186} \mathrm{Os}$ ratios from Site 959 agree with Pacific data or not. Only qualitative statements can be made safely. It is unambiguous that calculated initial ${ }^{187} \mathrm{Os} /{ }^{186} \mathrm{Os}$ ratios from the laminated diatomites are much lower than those of the Neogene samples, and generally similar to the inferred values of contemporaneous Pacific seawater. This provides additional evidence that much of the variation in the initial Os isotopic composition of these reducing sediments is controlled by the Os isotopic composition of seawater. The ranges of calculated initial ratios do not coincide exactly with the bulk of the Pacific data. They are, rather, slightly less radiogenic. Detailed interpretation of most of these data is hampered by poor age control and the fact that the marine Os record during this time interval is not well defined.

In the case of the single upper Oligocene sample, where both the Pacific seawater curve, as defined by metalliferous sediment data, and the sample age, approximately $24 \mathrm{Ma}$, are well constrained, it is clear that a discrepancy between the Pacific record and this datum exists (Fig. 3). The origin of the discrepancy cannot be determined based on the available data. Diagenetic redistribution of Re and/or Os, the influence of terrigenous Os, or a true contrast between the $\mathrm{Pa}-$ cific and the Atlantic may all contribute to this apparent discordance. Scatter in the lower Paleocene to Upper Cretaceous claystones about the reference isochron discussed below is similar in magnitude to scatter of the diatomite data about the Pacific seawater trend. This similarity suggests that diagenetic redistribution of Re and/or Os, and the influence of terrigenous Os render calculated initial ${ }^{187} \mathrm{Os} /{ }^{186} \mathrm{Os}$ ratios crude records of past variations in the Os isotopic composition of seawater.

It is critical to note that the interpretation given above requires that Os data from Deep Sea Drilling Project (DSDP) Site 596 (indi- cated by open squares in Figure 3) be recognized as an inaccurate record of past changes in the ${ }^{187} \mathrm{Os} /{ }^{186} \mathrm{Os}$ ratio of seawater. In their original work reporting the Os data from DSDP Site 596, PeuckerEhrenbrink et al. (1995) made a strong case that this pelagic clay sequence provides a flawed record of past changes in Os-isotopic composition of seawater by comparing Os isotopic data from selective leaches and bulk analyses of pelagic clays. If pelagic clay-leach data and metalliferous sediment data are regarded as equally reliable indicators of the marine Os isotope record, a strong case cannot be made that the upper Oligocene datum from Site 959 is discordant with $\mathrm{Pa}-$ cific data. The author does not concur with this interpretation of the data, but presents it here solely for the sake of clarity.

\section{Lower Paleocene to Upper Cretaceous Claystones}

A set of 10 lower Paleocene to Upper Cretaceous black claystone samples were also analyzed. These samples span a total depth range of approximately $38 \mathrm{~m}$ in Hole 959D and therefore represent some finite but unknown range in age. A crude estimate of the range in age represented by these samples can be obtained by assuming a constant rate of sediment accumulation from the late Santonian $(\approx 1030 \mathrm{mbsf})$ through the early Paleogene (The Cretaceous/Tertiary boundary lies somewhere between 830 and $870 \mathrm{mbsf}$ ). As before, these age assignments are based on shipboard biostratigraphy. This assumption yields an average accumulation rate of approximately $11 \mathrm{~m} / \mathrm{m} . y$. , suggesting the time spanned by the samples studied here is roughly $3 \mathrm{~m} . \mathrm{y}$. This time span is significant not only because appreciable production of ${ }^{187} \mathrm{Os}$ by Re decay can occur in the deepest sample before deposition of the shallowest sample, but also because significant variations in the ${ }^{187} \mathrm{Os} /{ }^{186} \mathrm{Os}$ ratio of seawater are easily possible over a 3- to 4m.y. time span. In particular, excursions in the ${ }^{187} \mathrm{Os} /{ }^{186} \mathrm{Os}$ ratio of seawater across the Cretaceous/Tertiary boundary are expected based on Os-isotopic data from Pacific pelagic clays (Peucker-Erhenbrink et al., 1995).

In light of the diachronous nature of the sample suite and the potential for variations in initial ${ }^{187} \mathrm{Os} /{ }^{186} \mathrm{Os}$ ratio, it is not reasonable to expect the Re-Os data to yield an isochron in the strict sense. Figure 4 shows the Late Cretaceous to early Paleogene data plotted as measured ${ }^{187} \mathrm{Os} /{ }^{186} \mathrm{Os}$ ratio vs. ${ }^{187} \mathrm{Re} /{ }^{186} \mathrm{Os}$ ratio. A reference isochron corresponding to an age of $68 \mathrm{Ma}$, based on the half-life of Lindner et al. (1989), is also plotted. This age is consistent with age constraints placed on this portion of Hole 959D by shipboard biostratigraphy.

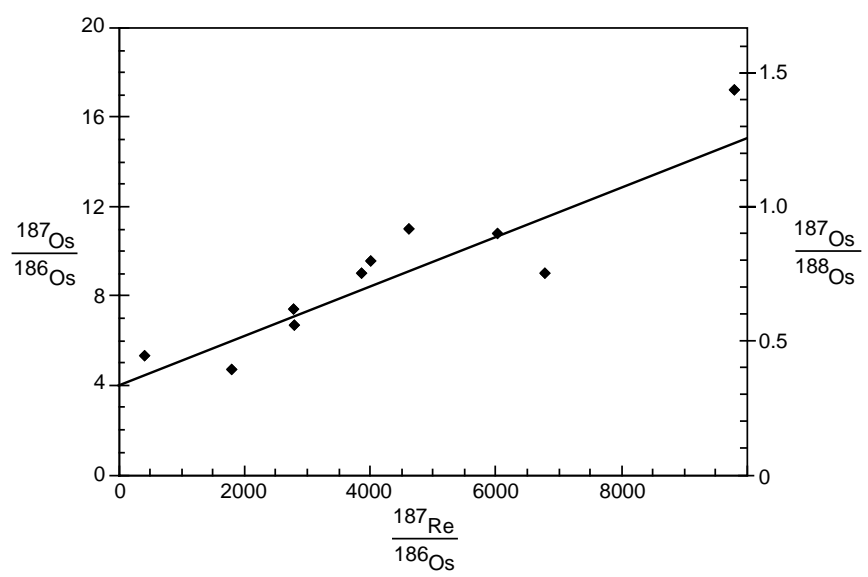

Figure 4. Plot of measured ${ }^{187} \mathrm{Os} /{ }^{186} \mathrm{Os}$ ratios vs. ${ }^{187} \mathrm{Re} /{ }^{186} \mathrm{Os}$ for data from analyses of Upper Cretaceous to lower Paleogene black claystones. The slope of the reference isochron corresponds to an age of $68 \mathrm{Ma}$, based on the ${ }^{187} \mathrm{Re}$ half-life reported by Lindner et al. (1989). The initial ${ }^{187} \mathrm{Os} /{ }^{186} \mathrm{Os}$ ratio of the reference isochron, 4.0, was chosen to agree with the few existing data that constrain the Os isotopic composition of Late Cretaceous seawater. 
The ${ }^{187} \mathrm{Os} /{ }^{186} \mathrm{Os}$ intercept of the reference isochron, 4.0, was chosen to agree with the few existing data that constrain the Os isotopic composition of Late Cretaceous seawater (Fig. 3). Although the initial ${ }^{187} \mathrm{Os} /{ }^{186} \mathrm{Os}$ ratio does not provide any independent constraint on the Os isotopic composition of seawater, the similarity of this value to other data constraining the Os-isotopic composition of Late Cretaceous seawater provides a qualitative indication that Os-isotopic variations in reducing sediments are largely controlled by the ${ }^{187} \mathrm{Os} /$ ${ }^{186}$ Os ratio of contemporaneous seawater at the time of deposition, and that subsequent changes in the Os-isotopic composition of these samples is mainly the result of in situ decay of ${ }^{187} \mathrm{Re}$.

\section{SUMMARY}

A broad survey of the Re-Os isotope systematics of sediments from Site 959 shows that over a range of depositional oxidationreduction conditions ranging from suboxic to anoxic, sediments are enriched in Re and Os relative to average crustal concentrations. In addition, Os-isotopic variations within these sediments are governed largely by the Os-isotopic composition of seawater at the time of their deposition and subsequent in situ decay of ${ }^{187} \mathrm{Re}$ to ${ }^{187} \mathrm{Os}$. The influence of nonhydrogenous Os likely carried by clastic material complicates direct application of data from bulk sediment analyses to reconstructions of past variations of the Os-isotopic composition of seawater.

\section{ACKNOWLEDGMENTS}

I thank my shipmates on Leg 159 for a great deal of help and support at sea. I also thank colleagues at WHOI, Jurek Blusztajn, Bernhard Peucker-Ehrenbrink, Doug Pyle, and Alberto Saal for analytical help and scientific input. Barry Grant's help with ICPMS Re and Ir analyses was also greatly appreciated. Comments from L. Reisberg and an anonymous reviewer improved the manuscript.

\section{REFERENCES}

Agiorgitis, G., and Wolf, R., 1984. Variations of the Os/Ir ratio in terrestrial rocks and minerals. Chem. Geol., 42:277-286.

Alvarez, L.W., Alvarez, W., Asaro, F., and Michel, H.V., 1980. Extraterrestrial cause for the Cretaceous-Tertiary extinction. Science, 208:10951108.

Anbar, A.D., Wasserburg, G.J., Papanastassiou, D.A., and Andersson, P.S., 1996. Iridium in natural waters. Science, 273:1524-1528.

Anders, E. and Grevasse, N., 1989. Abundances of the elements: Meteoritic and solar. Geochim. Cosmochim. Acta, 53:197-214.

Anderson, R.F., Fleisher, M.Q., and Le Huray, A.P., 1989. Concentration, oxidation state and particle flux of Uranium in the Black Sea. Geochim. Cosmochim. Acta, 53:2215-2224.

Barnes, C.E., and Cochran, J.K., 1990. Uranium removal in oceanic sediments and the oceanic U balance. Earth Planet. Sci. Lett., 97:94-101.

Basile, C., Mascle, J., Sage, F., Lamarche, G., and Pontoise, B., 1996. Precruise and site surveys: a synthesis of marine geological and geophysical data on the Côte d'Ivoire-Ghana Transform Margin. In Mascle, J., Lohmann, G.P., Clift, P.D., et al., Proc. ODP, Init. Repts., 159: College Station, TX (Ocean Drilling Program), 47-60.

Burton, K.W., Birck, J.-L., Allégre, C.J., Von Blankenburg, F., O’Nions, R.K., and Hein, J.R., 1996. Variations in the Osmium isotope ratio of seawater. J. Conf. Abstr., 1:92.

Colodner, D., Sachs, J., Ravizza, G., Turekian, K., Edmond, J., and Boyle E., 1993. The geochemical cycle of Rhenium: a reconnaissance. Earth Planet. Sci. Lett., 117:205-221.

Dymond, J., Suess, E., and Lyle, M., 1992. Barium in deep-sea sediment: a geochemical proxy for paleoproductivity. Paleoceanography, 7:163-182.
Esser, B.K., and Turekian, K.K., 1988. Accretion rate of extraterrestrial particles determined from osmium isotope systematics of Pacific pelagic clay and manganese nodules. Geochim. Cosmochim. Acta, 52:1383-1388.

, 1993. The osmium isotopic composition of the continental crust. Geochim. Cosmochim. Acta, 57:3093-3104.

Fenner, F.D., and Presley, B.J., 1984. Iridium in Mississippi River suspended matter and Gulf of Mexico sediment. Nature, 312:260-262.

Francois, R., Bacon, M.P., and Altabet, M.A., 1993. Glacial/interglacial changes in sediment rain rate in the SW Indian sector of subantarctic waters as recorded by $230 \mathrm{Th}, 231 \mathrm{~Pa}, \mathrm{U}$, and $\delta 15 \mathrm{~N}$. Paleoceanography, 8:611-629.

Hauri, E.H., and Hart, S.R., 1993. Re-Os isotope systematics of HIMU and EMII oceanic islands basalts from the south Pacific Ocean. Earth Planet. Sci. Lett., 114:353-371.

Hertogen, J., Janssens, M.-J., and Palme, H., 1980. Trace elements in ocean ridge basalt glasses: Implications for fractionations during mantle evolution and petrogenesis. Geochim. Cosmochin. Acta, 44:2125-2143.

Horan, M.F., Morgan, J.W., Grauch, R.I., Coveney, R.M., Murowchick, J.B., and Hulbert, L.J., 1994. Re-Os isotopes in black shales and Ni-Mo-PGErich sulfide layers, Yukon Territory, Canada, and Hunan and Guizhou Provinces, China. Geochim. Cosmochim. Acta, 58:257-268.

Klinkhammer, G.P., and Palmer, M.R., 1991. Uranium in the oceans: where it goes and why. Geochim Cosmochim Acta, 55:1799-1806.

Koide, M., Hodge, V.F., Yang, J.S., Goldberg, E.G., Calhoun, J., and Bertine, K.K., 1986. Some comparative marine chemistries of rhenium, gold, silver, and molybdenum. Appl. Geochem., 1:705-714.

Lindner, M., Leich, D., Russ, G.P., Bazan, J.M., and Borg, R.J., 1989. Direct determination of the half-life of 187Re. Geochim. Cosmochim. Acta, 53:1597-1606

Mascle, J., Lohmann, G.P., Clift, P.D., et al., 1996. Proc. ODP, Init. Repts., 159: College Station, TX (Ocean Drilling Program).

Morgan, J.W., Wanderless, G.A., Petrie, R.K., and Irving, A.J., 1981. Composition of the earth's upper mantle. 1. Siderophile trace elements in ultramafic nodules. Tectonophysics, 75:47-67.

Murray, R.W., Leinen, M., and Isern, A.R., 1993. Biogenic flux of Al to sediment in the central equatorial Pacific Ocean: evidence for increased productivity during glacial periods. Paleoceanography, 8:651-670.

Orth, C.J., Quintana, L.R., Gilmore, J.S., Barrick, J.E., Haywa, J.N., and Spesshardt, S.A., 1988. Pt-group metal anomalies in the Lower Mississippian of southern Oklahoma. Geology, 16:627-630.

Orth, C.J., Quintana, L.R., Gilmore, J.S., Grayson, R.C., and Westergaard, E.H., 1986. Trace element anomalies at the Mississippian/Pennsylvanian boundary in Oklahoma and Texas. Geology, 14:986-990.

Pegram W.J., Krishnaswami, S., Ravizza G., and Turekian, K.K., 1992. The record of sea water ${ }^{187} \mathrm{Os} /{ }^{186} \mathrm{Os}$ variation through the Cenozoic. Earth Planet. Sci. Lett., 113:569-576.

Peucker-Ehrenbrink, B., Ravizza, G., and Hofmann, A.W., 1995. The marine ${ }^{187} \mathrm{Os} /{ }^{186} \mathrm{Os}$ record of the past 80 million years. Earth Planet. Sci. Lett., 130:155-167.

Ravizza, G., 1993. Variations of the ${ }^{187} \mathrm{Os} /{ }^{186} \mathrm{Os}$ ratio of seawater over the past 28 million years as inferred from metalliferous carbonates. Earth Planet. Sci. Lett. 118:335-348.

Ravizza, G., and Pyle, D., in press. PGE and Os isotopic analysis of single sample aliqouts with NiS fire assay preconcentration. Chem. Geol.

Ravizza, G., and Turekian, K.K., 1989. Application of the ${ }^{187}$ Re- ${ }^{187}$ Os system to black shale geochronometry. Geochim. Cosmochim. Acta, 53:3257-3262.

, 1992. The osmium isotopic composition of organic-rich marine sediments. Earth Planet. Sci. Lett., 110:1-6.

Roy-Barman, M., and Allégre, C.J., $1994 .{ }^{187} \mathrm{Os} /{ }^{186} \mathrm{Os}$ of mid-ocean ridge basalts and abyssal peridotites. Geochim. Cosmochim. Acta, 58:50435054 .

Date of initial receipt: 14 September 1996

Date of acceptance: 22 April 1997

Ms 159SR-035 